Uşak Üniversitesi Sosyal Bilimler Dergisi

$2014,7 / 4$

\title{
Sınıf Öğretmenlerinin 12 Yıllık (4+4+4) Zorunlu Eğitime İlişkin Görüşleri
}

\section{Özet}

\author{
Bülent ÖZDEN* \\ Remzi KILIÇ** \\ Dursun AKSU ${ }^{* *+}$
}

$\mathrm{Bu}$ araştırmanın amacl; 12 yıllık $(4+4+4)$ zorunlu eğitime yönelik sınıf öğretmenlerinin uygulama öncesinde eğitim sistemindeki değişimlere bakışını ve öngörülerini, uygulama sonrasında da uygulamada karşılaştıkları sorunları, uygulamaya yönelik beğenilerini ve görüşlerindeki değişimleri belirlemektir. Araştırma, sınıf öğretmenlerinin uygulama başlamadan önce ve uygulamanın birinci yılı sonunda 12 yıllık $(4+4+4)$ zorunlu eğitime yönelik görüşlerini almak ve bu görüşleri karşılaştırmak amacıyla nitel araştırma yöntemlerinden durum çalışması olarak desenlenmiştir. Araştırmanın çalışma grubunu İstanbul ili Kadıköy, Üsküdar, Ümraniye, Pendik, Sultanbeyli ilçelerinde görev yapan toplam 23 (7 erkek, 16 kadın) sınıf öğretmeni oluşturmaktadır. Araştırmada veri toplamak amacıyla araştırmacılar tarafından geliştirilen görüşme formu kullanılmıştır. Görüşme formu 4 açık uçlu sorudan oluşmaktadır. Bu sorular, eğitim-öğretime başlama yaşı, kademelendirme, öğretmenlik mesleği ve öğrenci gelişimi boyutlarını içermektedir. Araştırma sonucunda sınıf öğretmenleri 12 ylllık (4+4+4) zorunlu eğitime yönelik: 1) İlkokula 60-66 aylıkken başlayan öğrencilerin akademik başarılarının diğer öğrencilere göre daha düşük olduğu, özellikle okuma ve yazmayı öğrenme süreci açısından bu yaş aralığının uygun olmadığı ve bu yaş aralığındaki çocukların okul olgunluğu açısından yeterli olmadıklarını, 2) Uygulama için gerekli pilot uygulamanın yapılmadığı ve alt yapının yetersiz olduğunu, özellikle beşinci sınıfın ortaokul kademesine alınması ile birçok sınıf öğretmenin norm fazlası duruma düştüğünü, 3) Özellikle küçük yaştaki çocuklarla büyük yaştaki çocukların aynı yerleşke içinde yer almalarının yarattığı sorunun yapılan bu değişiklikle engelleneceğini, 4) Sınıf yönetiminin zorlaşması ve öğretim hizmeti dışındaki durumlarla uğraşılmasına neden olduğu, 5) Öğrencilerin beşinci sınıfta branş öğretmenleriyle tanışmalarının onların ilgi ve yeteneklerinin ortaya

\footnotetext{
* Dr, Marmara Üniversitesi Atatürk Eğitim Fakültesi İlköğretim Bölümü, bulent.ozden@marmara.edu.tr

** Dr, Niğde Üniversitesi Eğitim Fakültesi İlköğretim Bölümü, remziklc@nigde.edu.tr

*** Dr, Sakarya Üniversitesi Eğitim Fakültesi İlköğretim Bölümü, aksu@sakarya.edu.tr
} 
çıkmasında faydalı olacağını ve 6) 60-66 aylık çocuklarda başaramama korkusu oluştuğu be nedenle sınıf içinde gelişimsel farklllıklarının artmasının öğrencilerin kendilerini ifade etmelerini olumsuz etkilediğini belirtmişlerdir.

Anahtar Kelimeler: Okul Kademeleri $(4+4+4)$, Sınıf Öğretmenleri, Zorunlu Eğitim.

\title{
The Opinions of the Classroom Teachers Towards the 12 - Year - Compulsory Education (4+4+4) Application
}

\begin{abstract}
The aim of this research is to analyze the views and the predictions of the classroom teachers towards the changes in the educational system before the application of the 12-year-compulsory education $(4+4+4)$, the problems that they have encountered after the application, their admirations on the applications and the changes in their opinions. The study was designed according to the case study in order to take the opinions of the classroom teachers towards the 12-year-compulsory education both before the application and one year after the application and to compare their opinions. The study group of the research consisted of 23 classroom teachers (7 males and 16 females) that work in Kadıköy, Üsküdar, Ümraniye, Pendik and Sultanbeyli districts in Istanbul. The interview form developed by the researchers was used to collect data. It includes 4 open-ended questions. These questions have the dimensions like the age to start formal education, staging, teaching job and student improvement. According to the results of the study, the classroom teachers indicated regards the 12 -year-compulsory education that (1) the students who start school at the age of 60-66 months are academically less successful than the others and this age gap isn't appropriate to teach reading and writing since the children at this age aren't mature enough for attending school; (2) the necessary piloting hasn't been realized for the application and the substructure isn't sufficient and a lot of classroom teachers have encountered the norm surplus problem since the fifth grade was taken into the middle school grades; (3) the problem created by the fact that especially younger students and older students are in the same campus will be hindered with this change; (4) the application has caused teachers to deal with the other cases except from teaching and the application has made classroom management difficult; (5) the fact that
\end{abstract}


students meet their branch teachers in the fifth grade will be beneficial in terms of revealing their interest and skills and; (6) the children at the age of 60-66 months have suffered from failure fear, so increasing the progressive differences inside a classroom affect the students' abilities to express themselves negatively.

Key Words: Schooling Level, Classroom Teacher, Compulsory Education.

\section{Giriş}

Bilgi, insanlık tarihinin her döneminde önemli olmakla beraber iletişim imkânlarının küçülttüğü dünyamızda en önemli etken haline gelmiştir. Bilginin kazanılmasında, kullanılmasında ve bilgi gücünün üretilmesinde en önemli görev şüphesiz eğitim sistemlerindedir. Eğitim, insanların hayatındaki en dinamik öğelerden biridir ve toplumsal alanda meydana gelen değişimlerden en hızlı etkilenen ve aynı ölçüde toplumu etkileyen unsurdur. Bu çerçevede eğitimle ilgili politikaların belirlenmesi ve buna yönelik gerekli düzenlemeler ülkemizde Milli Eğitim Bakanlı̆̆ı eliyle yapılır. MEB de kanun, tüzük, yönetmelik ve genelgelerle bu değişimlerin tüm eğitim sistemine entegrasyonunu sağlamaktadır.

Eğitim sistemi içinde ilköğretim kurumları, öğrencilerin hem toplumsal rollerini benimsemeleri hem de daha sonraki eğitim ortamlarına hazırlanmaları açısından temel basamak durumundadır. Her düzeydeki eğitim kurumlarında olduğu gibi ilköğretim kurumlarında da eğitim uygulamalarının niteliğini en çok etkileyen değişkenlerin başında eğitim programları gelmektedir (Yılmaz 2006, s.1). Eğitim sistemlerinin temelini eğitim programlarının oluşturduğu düşünüldüğünde; uygulanan programların aksaklık ve eksikliklerinin giderilmesi, programların toplumsal ve bilimsel değişmelere göre yeniden düzenlenmesi ve bununla beraber eğitimde niteliğin artması beklenir (Erden 1993, s.1).

Eğitim sistemimizdeki önemli değişikliklerden biriyle 18/08/1997 tarihinde 23084 sayılı Resmi Gazetede yayımlanarak yürürlüğe giren 4306 sayılı kanunla, kesintisiz 8 yıllık zorunlu eğitime geçiş yapılmıştır. 18/08/1997 tarihinde 23084 sayılı Resmi Gazetede yayımlanarak yürürlüğe giren 4306 sayılı kanunla, eğitim sistemimizdeki önemli değişikliklerden biri olan, kesintisiz 8 yıllık zorunlu eğitime geçiş yapılmıştır. Bu değişim kanunda "İlköğretim kurumları sekiz yıllık okullardan oluşur. Bu okullarda kesintisiz eğitim yapılır ve bitirenlere ilköğretim diploması verilir" şeklinde ifadesini bulmuştur (Resmi Gazete, 1997). Böylece 5 yıl süren ilkokul ve 3 yıl 
süren ortaokul olarak kademelendirilen okullar yerini 8 yll kesintisiz öğrenim yapılan ilköğretim kurumuna bırakmıştır.

11/04/2012 tarihli ve 28261 sayılı Resmi Gazetede yayımlanarak yürürlüğe giren 30/03/2012 tarihli ve 6287 sayılı ilköğretim ve eğitim ile bazı kanunlarda değişiklik yapılmasına dair kanun ile zorunlu eğitim süresi 8 yıldan 12 yıla çıkarılmış ve bazı yeni uygulamalar gündeme gelmiştir. Buna göre zorunlu eğitim 4 yıl süreli ilkokul, 4 yıl süreli ortaokul ve 4 yıl süreli lise eğitimini kapsayacak şekilde düzenlenmiştir. 2012-2013 eğitim ve öğretim yılı için, 30 Eylül 2012 tarihi itibariyle 66 ayını tamamlayan tüm çocukların okul kayıt işlemleri e-okul sistemi üzerinden merkezi olarak yapılmıştır. Ayrıca 60-66 ay arasındaki çocukların ise velisinin yazılı isteği ile gelişim yönünde hazır olduğu anlaşılanların da ilkokula devamı sağlanmıştır (MEB, 2012a).

Zorunlu eğitim, örgün eğitimin en fazla önem verilen bölümünü ifade eder. İnsanın, belli bir çağda belli bir sürede eğitim almasını ön görür. Temel eğitim ise, hangi yaşta olursa olsun insanın; örgün ve yaygın eğitim sistemi içinde belli bir düzeyde ve nitelikte eğitim görmesini öngörür. 222 sayılı İlköğretim ve Eğitim Yasası'nda “İlköğretim her yurttaşın görmesi gereken temel eğitimdir" biçiminde tanımlanmıştır. 1739 sayılı Milli Eğitim Temel Yasasında kullanılan "temel eğitim" kavramı "ilköğretim" olarak değiştirilmiş ve T.C. Anayasasının 42. maddesinde "ilköğretim; kı, erkek bütün vatandaşlar için zorunludur ve devlet okullarında parasızdır" denilerek herkesin asgari ve temel seviyede eğitim almaları zorunlu kılınmıştır. İlköğretim; eğitim sisteminin ilk, orta ve yüksek şeklinde basamaklara ayrıldığı ülkelerde, okul sistemi yapısını belirlemek için kullanılan bir kavramdır ve her iki terim birbirinin yerini tutar biçimde kullanılmıştır (Güven, 2012).

Dünya genelinde 197 ülkenin 60'inda zorunlu eğitim süresi 8 yıl ve daha az süreler içerirken, 130'unda 9-12 yıl arası ve 7'sinde ise 13-14 yıllık eğitim veriliyor. Ülkelerin çoğunluğunda zorunlu eğitime başlama yaşı 6 iken, 38 ülkede zorunlu eğitime 6 yaştan önce başlanıyor. Zorunlu eğitime başlama yaşı 7 olan 44, 6 olan 113, 5 olan 33, 4 olan 4 ve 3 olan 1 ülke bulunuyor. Eğitim süresi de ülkelere göre farklılık gösteriyor. Zorunlu eğitim 5 ülkede 5 yıl, 24 ülkede 6 yıl, 11 ülkede 7 yıl, 20 ülkede 8 yıl, 54 ülkede 9 yıl, 34 ülkede 10 yıl, 20 ülkede 11 yıl, 22 ülkede 12 yıl, 6 ülkede 13 yıl, 1 ülkede ise 14 yıl. Böylece 197 ülkeden 60'inda zorunlu eğitim süresi 8 yıl ve daha az, 130'unda ise 12 yıla kadar zorunlu eğitim uygulanıyor. Avrupa Birliği ve öteki bazı ülkelerde zorunlu eğitim süresi çeşitlilik 
gösteriyor. Zorunlu eğitime başlama yaşı Belçika, Çek Cumhuriyeti, Danimarka, Almanya, İrlanda, Estonya, Fransa, İtalya, Avusturya, Romanya, Portekiz, Polonya, ABD, Avustralya, Kore, Japonya'da 6 olarak uygulaniyor. Bulgaristan, Finlandiya ve İsveç'te 7, Macaristan, Hollanda ve Malta'da 5, İngiltere'de ise 4-5 yaşındaki çocuklar zorunlu eğitime başlıyor. Dünyadaki uygulamalarda eğitimin yapılanmasında ilk kademe ilkokulların süreleri de değişiyor. İlköğretim süresi Almanya, Avusturya, Brezilya, Bulgaristan, Macaristan ve Rusya Federasyonu'nda 4 yll, Fransa, İtalya, Hindistan ve Pakistan'da 5 yıl, Japonya, Hollanda ve Güney Kore'de 6 yıl, Avustralya, Norveç ve Güney Afrika'da 7 yıl, İrlanda'da ise 8 yıl olarak uygulanıyor (UNESCO, 2011; Akt: Güven, 2012). Üzerinde uzlaşılmış bir sınıf gruplaması sistemi bulunduğunu belirtmek olası değildir ve mevcut uygulamalar halen değişim içindedir (ERG, 2012).

Milli Eğitim Bakanlığı yapılan bu değişikliğin olası faydalarını ve yapılan düzenlemenin gerekçelerini şu şekilde açılamıştır (MEB, 2012b):

$\checkmark$ Toplam nüfusun ortalama eğitim yılı artırılacak ve okullaşma oranındaki bölgesel farklılıklar da azaltılacaktır.

$\checkmark$ Değişik kademelerde oluşturulacak seçimlik derslerle tüm vatandaşlarımızın ve öğrencilerimizin eğitimden beklentileri, sosyal ve kültürel talepleri karşılanmaya çalışılacaktır.

$\checkmark$ Öğrenciler sporda, sanatta veya başka bir alanda yetenek sahibi ise veya bu alanların birinde kendini geliştirmek istiyorsa 5. sınıftan itibaren kendisine bu imkân tanınmış olacaktır.

$\checkmark$ Eğitimin kademelere bölünmesi ile kademeler arası yatay ve dikey geçişlere imkân tanınmış, esnek yapı sayesinde bireye yetenek ve gelişimine göre erken yaşlarda tercih hakkı tanınmıştır.

$\checkmark$ Yapılan değiş̧iklik ile ilköğretim çağı 6 - 13 yaş olarak değiştirilmiş ve Eylül ayı sonu itibarıyla 5 yaşını doldurmuş, 6 yaşına girmiş çocuklarımızın ilköğretime başlamalarına fırsat verilmiştir. Bu konuda dünya genelindeki uygulamalarla paralellik sağlanmış, erken yaşta eğitime başlayan bireyin bir yıl erken hayata adım atması sağlanmıştır.

$\checkmark$ Sekiz yıllık kesintisiz eğitimde 1. sınıf öğrencisi ile 8. sınıf öğrencisi aynı bahçede oyun oynuyor, aynı tuvaleti kullanıyor ve aynı kantinde alışveriş yapmak için sıraya giriyordu. Yetişkin öğrencilerin bedensel üstünlükleri karşısında alt sınıf öğrencileri ezilebiliyor, ortak mekânlardan yeterince yararlanamiyordu. Yeni sistem, yaş aralığını düşürerek ilkokulların ayrı binalarda, diğer okullara (ortaokul ve lise) devam eden öğrencilerin ise farklı binalarda eğitim yapmasına imkân tanımıştır. 
$\checkmark$ Özellikle ikinci kademe, yani ortaokullar, öğrencilerin daha özgür bir birey olarak sivil toplum ve demokratik devlet anlayışı gereğince eğitim süreçlerinde özgür ve karar değiştirme hakkına sahip olmalarına firsat vermektedir.

$\checkmark$ Eğitim süresinin önemi kadar, öğrencilerin sistem içindeki programlarda tercih değişikliği yapabilmeleri de en az o kadar önemlidir.

$\checkmark$ Yeni düzenleme ile ilkokul, ortaokul ve liseler bağımsız (fizikî olarak) oluşturulabileceği gibi, imkân ve şartların elverişli olmadığı yerlerde ortaokullarm ilkokullarla ya da liselerle birlikte oluşturulmasına da firsat verilmektedir.

$\checkmark$ Ortaokullar, program bütünlüğü korunarak, üst öğretim programlarının bütününe yönelik olarak fazla sayıda seçeneği barındırıp, lise öğrenim sürecinde yer alan programların tercih edilmesine fırsat verecek esneklikte tasarlanacaktır. Dünyada da temel dersler dişında bireylerin ilgi, istek ve yeteneklerine uygun seçmeli derslerden oluşan seçimlik ders programları uygulanmaktadir.

$\checkmark$ Yeni düzenleme ile ortaokul ve liselerde, Kuran-1 Kerim ve Hz. Peygamberimizin hayatının seçmeli ders olarak okutulması sağlanmıştır. Ayrıca ortaokullarda, yani ikinci 4 yıllık kademede Türkçe, Matematik, Fen, Sosyal Bilgiler ve Yabancı Dil gibi temel dersler dışında seçimlik dersler ile lise eğitimi için alt yapı oluşturulacaktır. Ortaokullardaki zorunlu dersler dışındaki seçimlik dersleri, öğrencinin veya ebeveyninin isteğine ve tercihine bağlı olarak alabilme hakkı getirilmektedir. Böylece bireylerin demokratik hak ve taleplerine sınırlama değil, aksine seçme hakkı sağlanarak bireylere ilgi, istek ve yeteneklerine uygun bir eğitim alma yönünde taleplerinin karşılanması imkânı sağlanmıştır.

Her ne kadar MEB 12 yıllık zorunlu eğitim ve yeni kademelendirme sisteminin 8 yıllık kesintisiz eğitime oranla daha üstün ve başarılı olduğunu savunsa da yeni sistem gündeme geldiği günden bu yana kamuoyu tarafından çok tartışılmış ve birçok eleştiri gündeme getirilmiştir. 12 yıllık zorunlu eğitim sistemi ve yeni kademelendirme ile ilgili yapılan eleştiriler (Doğan vd. 2014; Durmuşçelebi Bilgili, 2014; Yılmaz vd. 2014; Aykaç vd. 2014); 
1. Yeterince hazırlık yapılmadan ve bilimsel temellerden yoksun olarak hayatı geçirildiği

2. Okul binalarının yapılan ayrıştırmaya uygun olmaması

3. Üst programlara yönelik yeni seçeneklerin olmasına bağlı olarak öğretmen sayısı ve fiziki alt yapının uygun olmayışı nedeniyle bir takım sorunlara sebebiyet verebileceği

4. Öğretmenlerin sistemle birlikte gelen yeni yaş grubu(60-66 ay) ile çalışma konusunda ne ölçüde yeterliliğe sahip oldukları

5. Farklı yaş grubundaki çocukların aynı sınıfta öğrenim görmesine bağlı olarak özellikle 66 aylık çocukların fiziksel, zihinsel ve bedensel yeterliliklerinin diğer öğrencilere göre geri olmasından dolayı başarısızlık, güvensizlik ve okula karşı korku geliştirmeleri ve buna bağlı olarak okuldan uzaklaşmalarına neden olabileceği şeklinde özetlenebilir.

Eğitim sistemleri "açık sistem" özelliğini taşırlar. Bu sebeple ulusal ve uluslararası düzeydeki ekonomik, sosyal, kültürel ve siyasal değişmelerden ve gelişmelerden etkilenirler. Ancak bu çok yönlü gelişme ve değişmelere uyum sağlarken, bir sistem olarak istikrarlarını ve etkinliklerini de sürdürmek zorundadırlar. Türk eğitim sisteminin zayıf yönlerinden biri, değişmelere ve gelişmelere uyum sağlamaya çalışılırken, istikrarı ve etkinliği sürdürecek önlemlerin alınmasında yeterli dengenin sağlanamamasıdır. Özellikle 1980'li yıllardan itibaren Türk eğitim sisteminde uygulamaya konulan, ancak henüz olumlu/olumsuz sonuçları alınmadan uygulamadan kaldırılan çok sayıda değişiklik yapılmıştır. Bu değişikliklerin sorunlara çözüm arama ve değişime uyma çabalarının bir ürünü olduğundan şüphe duyulmamaktadır. Ancak, bir sistem bütünlüğü içerisinde ele alınmayan ve gerekli alt yapı oluşturulmadan uygulamaya konulan değişikliklerin getirdiği çözümlerden çok sorun ürettikleri de göz ardı edilmemelidir (Kalkınma ve Özel İhtisas Komisyonu Raporu, 2009)

Karip'e (1997) göre karmaşık bir süreç olan eğitimde değişme sürecinin etkililiği, değişim plan ve politikalarının uygulanmasını etkileyen etkenlerin belirlenmesi ve kontrol edilebilmesine bağlıdır. Eğitim sistemlerindeki değişim süreçlerinde gelişmelere göre kararlar alınabilmesi ve karar alma sürecine temel eğitim paydaşlarından birisi olan öğretmenlerin de katılması gerekmektedir. Bu nedenle öğretmenler uygulamanın yürütülmesiyle ilgili konularda görüş birliğinin sağlanması ve problemlerin tartışılması amacıyla düzenli olarak bir araya gelmesi gerektiği söylenebilir.

Gelişmiş ülkelerin eğitim sistemleri incelendiğinde, bilgi tabanlı bilgi toplumu sürecinde, eğitim sistemlerinin tüm katılımcılar ile birlikte 
tartışılmakta ve buna göre reform çalışmalarının yapılmakta olduğu görülmektedir (Eraslan, 1999). Yapılan reformlardan başarı elde edilmesinde en önemli etkenin öğretmen olduğu da açık bir gerçektir (Kalkınma ve Özel İhtisas Komisyonu Raporu, 2009).

Öğretimin niteliği bakımından öğretmen yetiştirme ve öğretmenlerin mesleki gelişimlerinin desteklenmesi her zaman öncelikli bir gereklilik olmuştur. Sistem değişikliği gibi kapsamlı değişiklikler bu desteğin gerekliliğini daha da artıran durumlardır. Bu tür süreçlerin en az sorunla atlatılması için öncelikle öğretmen görüşlerine başvurulması ve buradan elde edilen sonuçlardan yola çıkarak sürecin desteklenmesi gerekmektedir (Yılmaz vd. 2014). 6287 sayılı kanunda yapıldığı gibi kanunlarda, tüzüklerde, yönetmeliklerde ve genelgelerde yer alan hususların okullarda uygulanması, toplumsal yaşama etkisi, okul yöneticileri, öğretmenler ve öğrencileri ne ölçüde ve hangi yönde etkileyeceği eğitim sisteminin geleceği adına önemlidir.

$\mathrm{Bu}$ çalışma ile sınıf öğretmenlerinin uygulama öncesinde eğitim sistemindeki değişimlere bakışını ve öngörülerini, uygulama sonrasında da uygulamada karşılaştıkları sorunları, uygulamaya yönelik beğenilerini ve görüşlerindeki değişimleri belirlemek amaçlanmıştır.

\section{Yöntem}

\section{Araştırmanın Modeli}

$\mathrm{Bu}$ araştırma, sınıf öğretmenlerinin uygulama başlamadan önce ve uygulamanın birinci yılı sonunda 12 yıllık $(4+4+4)$ zorunlu eğitime yönelik görüşlerini almak ve bu görüşleri karşılaştırmak amacıyla nitel araştırma yöntemlerinden olan durum çalışmasına göre desenlenmiştir.

\section{Çalışma Grubu}

Araştırmanın çalışma grubunu, İstanbul ili Kadıköy, Üsküdar, Ümraniye, Pendik, Sultanbeyli ilçelerinde görev yapan toplam 23 (7 erkek, 16 kadın) sınıf öğretmeni oluşturmaktadır. Çalışma grubunda yer alan sınıf öğretmenlerinin mesleki kıdemlerine göre dağılımlar şu şekildedir: mesleki kıdemi 1-5 yıl arası olan dört öğretmen, 6-10 yıl arası altı öğretmen, 11-15 arası olan altı öğretmen ve 16 yıl ve üstü olan yedi öğretmen'dir.

\section{Veri Toplama Aracı}

Araştırmada veri toplamak amacıyla araştırmacılar tarafından geliştirilen görüşme formu kullanılmıştır. Görüşme formu 4 açık uçlu sorudan oluşmaktadır. Bu sorular, eğitim-öğretime başlama yaşı, 
kademelendirme, öğretmenlik mesleği ve öğrenci gelişimi boyutlarını içermektedir.

\section{Verilerin Toplanmasi}

Araştırma verileri, Kadıköy, Üsküdar, Ümraniye, Pendik, Sultanbeyli ilçelerinde görev yapan 23 sınıf öğretmeni ile yapılandırılmış görüşme tekniği kullanılarak toplanmıştır. Verilerin bir bölümü 12 yıllık zorunlu eğitime geçilmeden 2011-2012 öğretim yılında, diğer bölümü ise 12 yıllık zorunlu eğitimin uygulanmaya başlandığı birinci yılı olan 2012-2013 öğretim yılı sonunda toplanmıştır.

Verilerin Analizi

Yapılandırılmış görüşme tekniği kullanılarak toplanan nitel veriler içerik analiz tekniği kullanılarak analiz edilmiştir.

\section{Bulgular}

12 yıllık zorunlu eğitim uygulama öncesi ve uygulamanın birinci yılı sonunda sinıf öğretmenlerinin öğretime başlama yaşına yönelik görüşlerini belirlemek ve bu görüşleri karşılaştırmak amacıyla sorulan soruyla elde edilen bulgular Tablo-1'de verilmiştir. 
Tablo-1 Sınıf Öğretmenlerinin Öğretime Başlama Yaşına Yönelik Görüşleri

\begin{tabular}{|c|c|c|}
\hline & İLKOKULA BAŞLAMA YAŞIN & ÖNELİK ÖĞRETMEN GÖRÜŞLERİ \\
\hline & $\begin{array}{l}12 \text { YILLIK ZORUNLU EĞİTIM } \\
\text { UYGULAMA ÖNCESİ }\end{array}$ & $\begin{array}{c}12 \text { YILLIK ZORUNLU EĞİTIM BİRİNCİ } \\
\text { YILI SONU }\end{array}$ \\
\hline 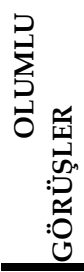 & $\begin{array}{l}\text { Erken yaşta öğrenme düzeyinin daha } \\
\text { yüksek olması nedeniyle uygundur. }\end{array}$ & - \\
\hline & $\begin{array}{l}\text { Okula başlama yaşının öne çekilmesi } \\
\text { çocukların okula hazırbulunuşlukları } \\
\text { açısından yanlıştır. }\end{array}$ & $\begin{array}{l}\text { İlkokula başlama yaşı okul olgunluğu } \\
\text { (fiziksel, psikolojik ve bilişsel gelişim) } \\
\text { açısından erkendir. }\end{array}$ \\
\hline & $\begin{array}{lrr}60 \text { aylık ve } 72 \text { aylık çocukların aynı } \\
\text { sinıfta olması küçük } & \text { çocukların } \\
\text { problemler yaşamasına } & \text { neden } \\
\text { olacaktır. } & & \\
\end{array}$ & $\begin{array}{l}\text { Mevcut sınıf koşulları ve ders saati süreleri } \\
\text { öğretime başlama yaşına uygun değildir. }\end{array}$ \\
\hline 舀 & $\begin{array}{l}\text { Okulda sosyal, duygusal ve bilişsel } \\
\text { anlamda sorunlar yaşanacağını } \\
\text { düşünüyorum. }\end{array}$ & $\begin{array}{l}\text { Hâlihazırdaki } 1 \text {. Sınıf öğretim programları } \\
\text { öğretime başlama yaşına uygun olmadığı } \\
\text { için sorunlar yaşanmıştır. }\end{array}$ \\
\hline : & $\begin{array}{l}\text { Öğrencilerin özbakım vb. açılardan } \\
\text { gelişim düzeyine bağlı olarak sorunlar } \\
\text { yaşayacağını düşünüyorum. }\end{array}$ & $\begin{array}{l}\text { Okuma yazmayı öğrenme süreci açısından } \\
\text { öğretime başlama yaşı uygun değildir. }\end{array}$ \\
\hline$\sum_{S}^{\infty}$ & & 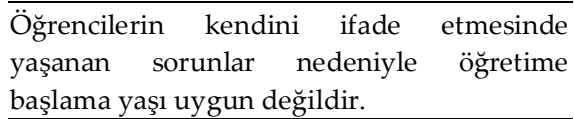 \\
\hline$\overline{0}$ & & $\begin{array}{l}\text { Öğretim yılı sonunda } 60-66 \text { aylık öğrencilerin } \\
\text { akademik başarıları diğer öğrencilere göre } \\
\text { daha düşük olması öğretime başlama yaşının } \\
\text { uygun olmadığını göstermektedir. }\end{array}$ \\
\hline
\end{tabular}

Tablo-1'de görüldüğü gibi araştırmaya katılan sınıf öğretmenleri 12 yıllık $(4+4+4)$ zorunlu eğitim düzenlemesinde ilkokula başlama yaşına yönelik daha çok olumsuz görüşler bildirmişlerdir. Sınıf öğretmenlerinin, 12 yıllık zorunlu eğitim uygulanmaya başlamadan önce, 60 ve 66 aylıkken ilkokula başlayan çocukların okula hazırbulunuşluklarının, özellikle öz bakım becerilerinin yeterli olmayacağı, kendilerinden büyük çocuklarla problemler yaşayabilecekleri, okulda sosyal, duygusal ve bilişsel anlamda sorunlar yaşayabilecekleri öngörülerinde bulunmuşlardır.

İlkokula başlama yaşına yönelik uygulamanın birinci yılının sonunda sinıf öğretmenlerinin bu uygulamaya yönelik görüşlerine bakıldığında uygulama öncesinde öne sürdükleri görüşlerle paralellik 
olduğu görülmektedir. Sınıf öğretmenlerine göre ilkokula 60-66 aylıkken başlayan öğrencilerin akademik başarılarının diğer öğrencilere göre daha düşük olduğu, özellikle okuma ve yazmayı öğrenme süreci açısından bu yaş aralığının uygun olmadığı, bu çocukların kendilerini ifade etmekte sorunlar yaşadıklarını kısaca bu yaş aralığındaki çocukların okul olgunluğu açısından yeterli olmadıkları görüşlerini belirtmişlerdir. Uygulama öncesinden ki görüşlerinden farklı olarak uygulama sonrasında sınıf öğretmenleri birinci sınıf öğretim programlarının bu yaş aralığında bulunan çocuklar için uygun olmadığı ve onlara yönelik gerek programlarda gerekse sınıf koşulları ve ders sürelerinde değişiklikler yapılmadığı için sorunlar yaşandığını belirtmişlerdir.

İlkokula başlama yaşına yönelik sadece uygulama öncesinde bir olumlu görüş ileri sürülmüştür. Buna göre, sinıf öğretmenleri erken yaşta öğrenme düzeyinin daha yüksek olması nedeniyle bu uygulamanın uygun olduğu belirtilmiştir.

12 yıllık zorunlu eğitim uygulama öncesi ve uygulamanın birinci yılı sonunda sınıf öğretmenlerinin $4+4+4$ olarak gerçekleştirilen kademelendirmeye yönelik görüşlerini belirlemek ve bu görüşleri karşılaştırmak amacıyla sorulan soruyla elde edilen bulgular Tablo-2'de verilmiştir. 
Tablo-2 Sınıf Öğretmenlerinin Kademelendirmeye Yönelik Görüşleri

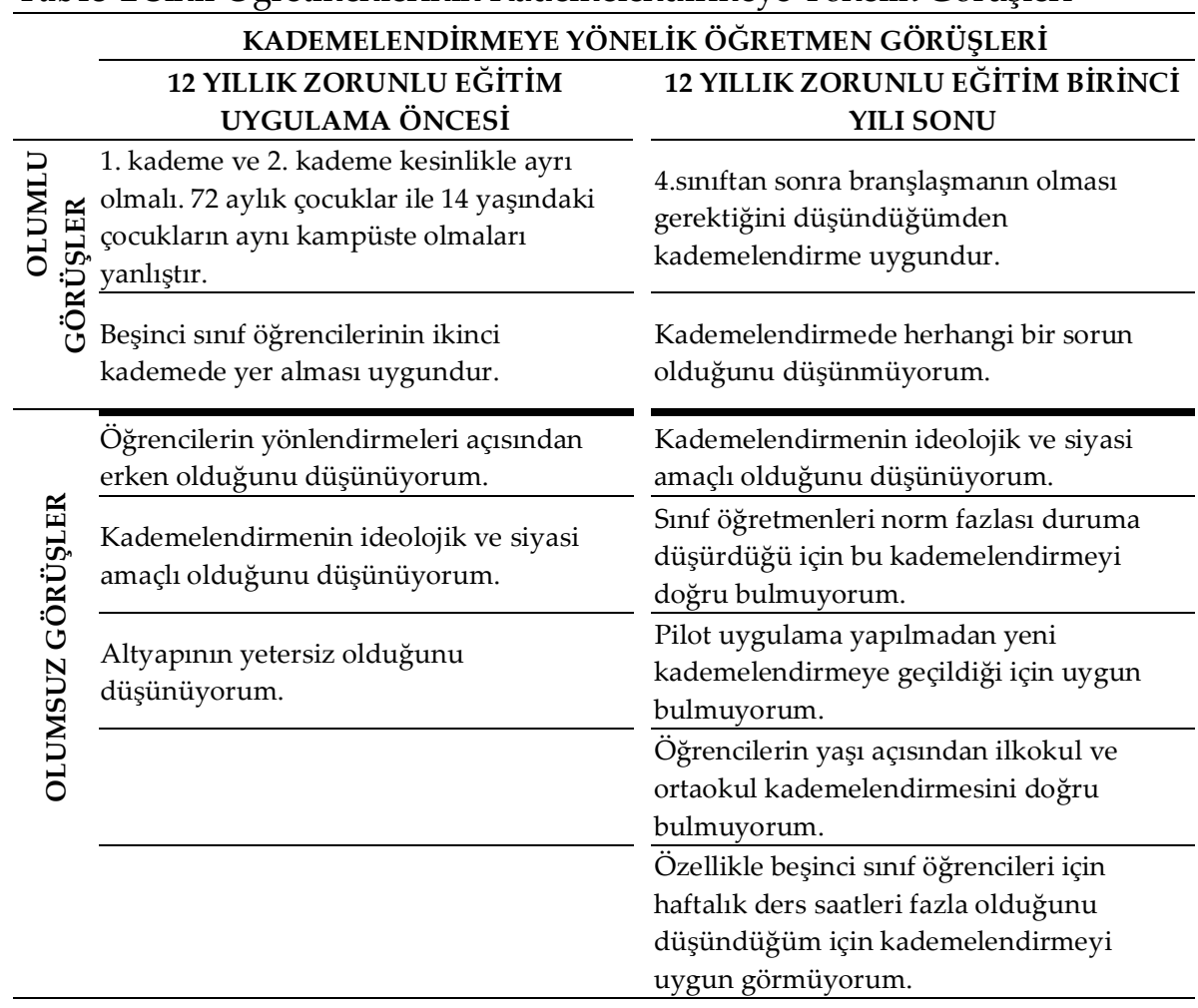

Tablo-2'de görüldüğü gibi sinıf öğretmenleri $4+4+4$ olarak gerçekleştirilen kademelendirmeye yönelik uygulama öncesi ve uygulamanın birinci yılı sonunda hem olumlu hem de olumsuz görüşler belirtmişlerdir. Sınıf öğretmenleri, kademelendirmeye yönelik olumlu görüşlerinde özellikle küçük yaştaki çocuklarla büyük yaştaki çocukların aynı yerleşke içinde yer almalarının sorun yarattığı ve yapılan bu değişiklikle yaşanan sorunların engelleneceğini ve 4 . sınıftan sonra derslere sinıf öğretmenlerinin yerine branş öğretmenlerinin girmesi gerektiğini vurgulamışlardır.

Sınıf öğretmenlerinin $4+4+4 \quad$ olarak gerçekleştirilen kademelendirmeye yönelik, hem uygulama öncesinde hem de uygulamanın birinci yılı sonunda ortak olumsuz görüşlerine bakıldığında yapılan değişikliğin ideolojik ve siyasi amaçlı olduğu, ayrıca bu uygulama için gerekli pilot uygulamanın yapılmadığı ve alt yapının yetersiz olacağını vurguladıkları görülmektedir. Bunların dışında sınıf öğretmenleri 
uygulamanın birinci yılı sonunda, özellikle beşinci sınıfın ortaokul kademesine alınması ile birçok sınıf öğretmenin norm fazlası duruma düştüğünü ve haftalık ders saatlerinin beşinci sınıf öğrencileri için fazla olduğunu vurgulayarak kademelendirmeye yönelik olumsuz yönde eleştiri getirmişlerdir.

12 yıllık zorunlu eğitim uygulama öncesi ve uygulamanın birinci yılı sonunda sınıf öğretmenlerinin uygulamayı öğretmenlik mesleği açısından değerlendirmeleri istenmiştir. Buna yönelik sınıf öğretmenlerinin görüşlerini belirlemek ve bu görüşleri karşılaştırmak amacıyla sorulan soruyla elde edilen bulgular Tablo-3' de verilmiştir.

Tablo-3 Sınıf Öğretmenlerinin Kademelendirmeyi Öğretmenlik Mesleği Açısından Değerlendirmeleri

\begin{tabular}{|c|c|c|}
\hline & \multicolumn{2}{|c|}{ ÖĞRETMENLİK MESLEĞİ AÇISINDAN ÖĞRETMEN GÖRÜŞLERİ } \\
\hline & $\begin{array}{l}12 \text { YILLIK ZORUNLU EĞİTİM } \\
\text { UYGULAMA ÖNCESİ }\end{array}$ & $\begin{array}{l}12 \text { YILLIK ZORUNLU EĞİTİM BİRİNCİ YILI } \\
\text { SONU }\end{array}$ \\
\hline \multirow{2}{*}{ 幽: } & $\begin{array}{l}\text { Öğretim sürecini olumlu } \\
\text { etkileyecektir. 5. sınıfların bir üst } \\
\text { kademeye geçişi sınıf } \\
\text { öğretmenlerinin yükünü } \\
\text { hafifletecektir. }\end{array}$ & $\begin{array}{l}\text { Son 10-12 yılda alan dışı öğretmen ataması } \\
\text { yapılmadığı için } 12 \text { yıllık zorunlu eğitimi } \\
\text { uygulama açısından öğretmenlerin } \\
\text { formasyonun yeterli olduğunu düşünüyorum }\end{array}$ \\
\hline & $\begin{array}{l}\text { Öğretmenlik mesleği açısından bir } \\
\text { değişiklik olmayacağını } \\
\text { düşünüyorum. }\end{array}$ & \\
\hline \multirow{4}{*}{ 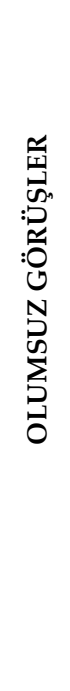 } & $\begin{array}{l}\text { Altyapı, program ve öğretmen } \\
\text { eğitimi yapılmadan uygulamaya } \\
\text { geçiliyor, öğretmen açısından zor } \\
\text { olacak. }\end{array}$ & $\begin{array}{l}\text { Pilot uygulama yapılmadan yeni sisteme } \\
\text { geçildiği için öğretmenlerin işi zorlaşmıştır. }\end{array}$ \\
\hline & $\begin{array}{l}\text { Sınıf öğretmenlerinin } 60-72 \text { aylık } \\
\text { çocuklara yönelik yeterli bilgi sahibi } \\
\text { olmaması nedeniyle olumsuz etkileri } \\
\text { olacaktır }\end{array}$ & $\begin{array}{l}\text { Birinci ve beşinci sınıf öğrencilerinin gelişimsel } \\
\text { özelliklerine, ilgilerine, ihtiyaçlarına ve bu } \\
\text { öğrencilere uygun öğrenme öğretme } \\
\text { süreçlerinin hazırlanmasına yönelik hizmet içi } \\
\text { eğitim verilmemesi öğretmenlerin sorunlar } \\
\text { yaşamasına neden olmuştur. }\end{array}$ \\
\hline & $\begin{array}{l}\text { Sınıfta farklı yaş grubunda } \\
\text { öğrencilerin olması öğretmen } \\
\text { açısından sorun olacak. }\end{array}$ & $\begin{array}{l}\text { Sınıfta farklı yaş gruplarında öğrencilerin } \\
\text { bulunması öğretmenlerin öğretimi } \\
\text { farklılaştırması ve sınıf yönetimi açısından } \\
\text { sorunlar yaşamasına neden olmuştur. }\end{array}$ \\
\hline & & $\begin{array}{l}\text { Okul olgunluğu yeterli düzeyde olmayan } \\
\text { öğrenciler nedeniyle öğretim hizmeti dışında } \\
\text { tuvalet alışkanlığı kazandırma, yemek yedirme, } \\
\text { ilaç içirme, vb. durumlarla uğraşılmıştır. }\end{array}$ \\
\hline
\end{tabular}


Tablo-3'de görüldüğü gibi 12 yılllk zorunlu eğitimin 4+4+4 şeklinde kademelendirilmesini öğretmenlik mesleği açısından değerlendiren sınıf öğretmenleri bu konuda hem olumlu hem de olumsuz görüşler belirtmişlerdir. Uygulama başlamadan önce, bazı sınıf öğretmenleri, $4+4+4$ şeklinde yapılan kademelendirmenin öğretmenlerin ders yükünü hafifleteceğini vurgulayarak kademelendirmeye olumlu yaklaşmışlardır. Uygulamanın birinci yılı sonunda, bazı sınıf öğretmenleri, sınıf öğretmenliği kadrosuna son yıllarda alan dışından kişilerin atamasının yapılmaması ve var olan öğretmenlerin 12 yıllık zorunlu eğitime geçişle getirilen değişikliklerin gerektirdiği bilgi ve beceriye sahip oldukları görüşünü vurgulayarak yine uygulamaya olumlu yaklaşmışlardır.

12 yıllık zorunlu eğitimin $4+4+4$ şeklinde kademelendirilmesini öğretmenlik mesleği açısından değerlendiren sınıf öğretmenlerinin gerek uygulama öncesi gerekse uygulamanın birinci yll sonunda belirttikleri olumsuz görüşlere bakıldığında, ögrretmenlerin özellikle altyapı, program ve pilot çalışması yapılmadan ve öğretmenlere özellikle 60-66 aylık çocukların gelişim özellikleri ve bunlara verilecek eğitime yönelik hizmet içi eğitim verilmeden uygulamaya geçilmesini, sinıflarda farklı yaş gruplarında öğrencilerin yer alması nedeniyle sınıf yönetimi ve öğretim sürecine yönelik sorunların yaşanması gibi durumları vurguladıkları görülmektedir. Bunun yanında uygulamanın birinci yılı sonunda sınıf öğretmenleri, okul olgunluğu yeterli düzeyde olmayan öğrenciler nedeniyle öğretim hizmeti dışında tuvalet alışkanlığı kazandırma, yemek yedirme, ilaç içirme, vb. durumlarla uğraştıklarını olumsuz bir durum olarak belirtmişlerdir.

12 yıllık zorunlu eğitim uygulama öncesi ve uygulamanın birinci yılı sonunda sınıf öğretmenlerinin ilkokula başlayan öğrencilere yönelik görüşlerini belirlemek ve bu görüşleri karşılaştırmak amacıyla sorulan soruyla elde edilen bulgular Tablo-4'de verilmiştir. 
Tablo-4 Sınıf Öğretmenlerinin İlkokula Başlayan Öğrencilere Yönelik Görüşleri

\begin{tabular}{|c|c|c|}
\hline & \multicolumn{2}{|c|}{ ÖĞRENCİ AÇISINDAN ÖĞRETMEN GÖRÜŞLERİ } \\
\hline & $\begin{array}{l}12 \text { YILLIK ZORUNLU EĞITIMM } \\
\text { UYGULAMA ÖNCESİ }\end{array}$ & $\begin{array}{c}12 \text { YILLIK ZORUNLU EĞITİM BİRİNCİ } \\
\text { YILI SONU }\end{array}$ \\
\hline 承 & $\begin{array}{l}\text { Öğrenciler, mesleki yönlendirmenin } \\
\text { daha erken yapılabilecek olması } \\
\text { nedeniyle olumlu etkilenecektir. }\end{array}$ & $\begin{array}{l}\text { Öğrencilerin beşinci sınıfta branş } \\
\text { öğretmenleriyle tanışması ilgi ve } \\
\text { yeteneklerinin ortaya çıkması adına faydalı } \\
\text { olabilir. }\end{array}$ \\
\hline \multirow{8}{*}{ 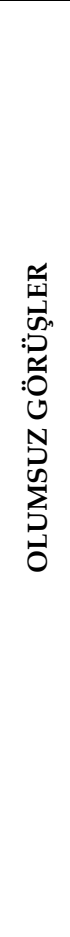 } & $\begin{array}{l}\text { Gelişimsel farklılıklarının artması } \\
\text { öğrencilerin kendini ifade etmesini, } \\
\text { eğitime bakış açısını olumsuz } \\
\text { etkileyecektir. }\end{array}$ & $\begin{array}{l}\text { 60-66 aylık öğrenciler için ilkokul ortamının } \\
\text { uygun olmadığını düşünüyorum. }\end{array}$ \\
\hline & $\begin{array}{l}\text { İlkokul birinci sınıfta okula uyum } \\
\text { probleminin daha uzun sürmesine } \\
\text { neden olacaktır. }\end{array}$ & 72 ayın altında öğrenciler okuldan korktular. \\
\hline & $\begin{array}{l}\text { İlk okuma yazma öğrenme süresini } \\
\text { uzatacaktır. }\end{array}$ & $\begin{array}{l}\text { Derslerin anlamlı gelmemesi, öğretmenlerin } \\
\text { öğrencileri zorlaması çocuklarda ruhsal } \\
\text { gerilim yaratmıştır. }\end{array}$ \\
\hline & $\begin{array}{l}\text { Erken yönlendirmenin olumsuz etkileri } \\
\text { olacaktır. }\end{array}$ & $\begin{array}{l}\text { 60-72 ay arası çocuklar etkinliklerde çabuk } \\
\text { yoruluyor ve sıkılıyorlar, ayrıca dikkat } \\
\text { dağınıklığı ve ilgisizlik yaşıyorlar. }\end{array}$ \\
\hline & $\begin{array}{l}\text { İlkokul birinci sınıf öğrencilerinin } \\
\text { hazırbulunuşluk düzeyinin yetersiz } \\
\text { olacağını düşünüyorum. }\end{array}$ & $\begin{array}{l}\text { 60-66 aylık öğrenciler yeterli okul } \\
\text { olgunluğuna sahip değildiler. }\end{array}$ \\
\hline & $\begin{array}{l}\text { İlkokula erken başlayan çocuklarda } \\
\text { başaramama korkusu oluşabilir. }\end{array}$ & $\begin{array}{l}\text { 60-66 aylık öğrenciler oyun yaşında okuma } \\
\text { yazma öğrenmeye çalışıyorlar. }\end{array}$ \\
\hline & \multirow[t]{2}{*}{$\begin{array}{l}\text { Öğrencilerin özbakım ihtiyaçları hem } \\
\text { öğrenci hem de öğretmen için sorun } \\
\text { olacaktır. }\end{array}$} & $\begin{array}{l}\text { 60-66 aylık öğrencilerin bir çoğu öz bakım } \\
\text { becerilerine sahip değillerdi. }\end{array}$ \\
\hline & & $\begin{array}{l}\text { Küçük yaş grubu büyük yaş grubunun içinde } \\
\text { kendini gösterememektedir. }\end{array}$ \\
\hline
\end{tabular}

Tablo-4'de görüldüğü gibi sinıf öğretmenleri 12 yıllık zorunlu eğitimi öğrenciler açısından değerlendirirken uygulama öncesinde öğrencilere mesleki yönlendirmenin daha erken yapılacak olmasını öğrenci açısından olumlu olacağını ön görmüşlerdir. Uygulamanın birinci yılı sonunda ise bazı sınıf öğretmenleri öğrencilerin beşinci sınıfta branş öğretmenleriyle tanışmalarının onların ilgi ve yeteneklerinin ortaya çıkmasında faydalı olacağını belirtmişlerdir. 
Uygulama öncesi ve uygulamanın birinci yılı sonunda sinıf öğretmenlerinin belirttikleri görüşlere bakıldığında, uygulama öncesinde öğretmenlerin 60-66 aylık çocukların sınıfa uyum sağlamalarında, özbakım ihtiyaçlarını karşılamalarında ve okuma yazmayı öğrenme sürecinde sorunlar yaşayacaklarını öngörmüşlerdir. Uygulamanın birinci yılı sonunda sınıf öğretmenlerinin değerlendirmelerine bakıldığında öğrencilerin hazırbulunuşluk, sınıfa ve okula uyum ve özbakım ihtiyaçlarına karşılamada sorunlar yaşadıkları görülmektedir. Bu durum, uygulama öncesinde öğretmenlerin belirttikleri görüşlerle paralellik göstermektedir.

Uygulamanın birinci yılı sonunda sınıf öğretmenleri, 60-66 aylık çocuklar için derslerin anlamlı gelmediğini ve öğretmenlerin bu çocukları zorladığını bunun sonucunda ise öğrencilerin ruhsal gerilimler yaşadıklarını belirtmişlerdir. $\mathrm{Bu}$ değerlendirme, öğretmenlerin uygulama öncesinde ilkokula erken yaşta başlayan çocuklarda başaramama korkusu oluşabilir görüşü ile paralellik göstermektedir. Diğer yandan uygulamanın birinci yılı sonunda 60-66 aylık öğrencilerin yaşça büyük olan diğer öğrencilerin arasında kendilerini gösteremediklerini belirtmişlerdir. Yine bu değerlendirme, uygulama öncesinde sınıf öğretmenlerinin öngördüğü sınıf içinde gelişimsel farklılıklarının artmasının öğrencilerin kendilerini ifade etmelerini olumsuz etkileyeceği öngörüsünü destekler niteliktedir.

\section{Sonuç ve Tartışma}

Uygulamanın birinci yılının sonunda sınıf öğretmenlerinin İlkokula başlama yaşına yönelik görüşlerine bakıldığında uygulama öncesinde öne sürdükleri görüşlerle paralellik olduğu görülmektedir. Sınıf öğretmenlerine göre ilkokula 60-66 aylıkken başlayan öğrencilerin akademik başarılarının diğer öğrencilere göre daha düşük olduğu, özellikle okuma ve yazmayı öğrenme süreci açısından bu yaş aralığının uygun olmadığı, bu çocukların kendilerini ifade etmekte sorunlar yaşadıklarını kısaca bu yaş aralığındaki çocukların okul olgunluğu açısından yeterli olmadıkları görüşlerini belirtmişlerdir. Sınıf öğretmenlerinin 12 yıllık zorunlu eğitimle birlikte değişen ilkokula başlama yaşına ilişkin görüşlerini destekler nitelikte Aykaç, Kabaran, Atar ve Bilgin (2014) 12 yıllık zorunlu eğitim uygulamasında birinci sınıftaki çocukların yaşadıkları sorunlara yönelik öğretmen görüşlerini belirledikleri araştırmalarında 60-66 ay arası çocukların bedensel ve zihinsel gelişimlerinin 1. sınıfta öğrenim görebilmeleri için yeterli olmadığını; Doğan, Uğurlu ve Demir (2014), araştırmalarına katılanların 
okula başlama yaşının 60-66 ay aralığına düşürülmesinin süreçteki tüm taraflar açısından olumsuz bir gelişme olduğunu ve öğrencilerin psikolojik ve fiziksel olarak okula başlamaya hazır olmadıklarını; Yılmaz, Taşçı, Fidan ve Nurlu (2014), öğrencilerin okul olgunluğu ve formal eğitime hazırbulunuşluğu bakımından eksik olduklarını; Öztürk ve Uysal (2013) 6066 aylık öğrenci grubunun seslerin yazılışını kavramakta ve seslerin görsel ifadelerini tanımakta güçlük çektiklerini, işitsel algı olarak ifadelendirilen komutları ve ifadeleri tam olarak anlamadıklarını belirtmişlerdir.

Sınıf öğretmenleri $4+4+4$ olarak gerçekleştirilen kademelendirmeye yönelik uygulama öncesinde ve birinci yılın sonunda hem olumlu hem de olumsuz görüşler belirtmişlerdir. Sınıf öğretmenleri, kademelendirmeye yönelik olumlu görüşlerinde özellikle küçük yaştaki çocuklarla büyük yaştaki çocukların aynı yerleşke içinde yer almalarının yarattığı sorunun yapılan bu değişiklikle engelleneceğini vurgulamışlardır. Bu sonucu destekler nitelikte Doğan ve arkadaşları (2014) ilköğretim okulunun ilkokul ve ortaokul olarak ayrılmasıyla fiziksel ve psikolojik olarak benzer gelişim dönemlerinde olan öğrencilerin bir arada olmasının olumlu karşılandığg, bunun öğrencilerin aynı yaş grubu içinde kendilerini daha güvende hissetmeleri ve üst sinıfların alt sinıflar üzerindeki baskısını ortadan kaldırması gibi olumlu sonuçlar doğurduğunu belirtmişlerdir.

4+4+4 olarak gerçekleştirilen kademelendirmeye yönelik, hem uygulama öncesinde hem de uygulamanin birinci yılı sonunda ortak olumsuz görüşlerine bakıldığında yapılan değişikliğin ideolojik ve siyasi amaçlı olduğu, ayrıca bu uygulama için gerekli pilot uygulamanın yapılmadığı ve alt yapının yetersiz olduğunu vurguladıkları özellikle beşinci sınıfın ortaokul kademesine alınması ile birçok sınıf öğretmenin norm fazlası duruma düştüğünü ve haftalık ders saatlerinin beşinci sinıf öğrencileri için fazla olduğunu vurgulayarak kademelendirmeye yönelik olumsuz yönde eleştiri getirdikleri görülmektedir. Araştırmada sınıf öğretmenlerinin kademelendirmeye ilişkin belirttikleri görüşleri destekler nitelikte Aykaç ve arkadaşları (2014) uygulamada yaşanan sorunların temel nedenlerinden biri olarak 12 yıllık zorunlu eğitimin bir deneme çalışması yapılmadan faaliyete geçirilmesidir. Doğan ve arkadaşları (2014), Durmuşçelebi ve Bilgili (2014) ise 5. Sınıfların ortaokula dahil edilmesiyle bu sinıflarda görev yapan öğretmenlerin norm fazlası durumuna düştüğü ve bu durumun öğretmenleri olumsuz etkilediğini vurgulamışlardır.

12 yıllık zorunlu eğitimin $4+4+4$ şeklinde kademelendirilmesini öğretmenlik mesleği açısından değerlendiren sınıf öğretmenleri bu konuda hem olumlu hem de olumsuz görüşler belirtmişlerdir. Uygulama başlamadan önce, bazı sınıf öğretmenleri, $4+4+4$ şeklinde yapılan 
kademelendirmenin öğretmenlerin ders yükünü hafifleteceğini vurgulayarak kademelendirmeye olumlu yaklaşmışlardır. $\mathrm{Bu}$ sonucu destekler nitelikte Külekçi (2013) araştırmasında 5. Sınıfların ortaokula geçmesiyle sınıf öğretmenlerinin yükünün azaldığını belirtmiştir. Örs, Erdoğan ve Kipici (2013) ise 5. sınıfların ortaokula dahil olmasıyla öğretmen daha az öğrenci ile daha fazla ilgilenebileceğini vurgulamışlardır. 12 yıllık zorunlu eğitimin $4+4+4$ şeklinde kademelendirilmesini öğretmenlik mesleği açısından değerlendiren sınıf öğretmenleri pilot uygulamanın yapılmaması, hizmet içi eğitim verilmemesi, programlarda gerekli değişikliklerin yapılmaması, yaş grubu farklılıklarından dolayı sınıf yönetiminin zorlaşması, okul olgunluğu yeterli düzeyde olmayan öğrenciler nedeniyle öğretim hizmeti dışında tuvalet alışkanlığı kazandırma, yemek yedirme, ilaç içirme, vb. durumlarla uğraşılması gibi olumsuz görüşler bildirmişlerdir. Aykaç ve arkadaşları (2014) deneme çalışmasının gerekliliğini, Yılmaz ve arkadaşları (2014) ve Durmuşçelebi ve Bilgili (2014) öğretmenlere hizmet içi eğitim verilmesi gerekliliğini vurgulamaları araştırmanın sonuçlarını desteklemektedir. Aynı zamanda araştırmanın sonuçlarını destekler nitelikte Yılmaz ve arkadaşları (2014) öğretmenlerin 60-66 aylık öğrencileri eğitim ve öğretim ortam ve etkinliklerine aktif olarak katmakta zorlandıkları ve bu öğrencilerin özbakım becerileri gibi okul olgunluğu bakımından formal eğitime tam olarak hazır olmadıklarını belirtmişlerdir.

Sınıf öğretmenleri 12 yıllık zorunlu eğitimi öğrenciler açısından değerlendirirken uygulama öncesinde öğrencilere mesleki yönlendirmenin daha erken yapılacak olmasını öğrenci açısından olumlu olacağını ön görmüşlerdir. Uygulamanın birinci yılı sonunda ise bazı sınıf öğretmenleri öğrencilerin beşinci sınıfta branş öğretmenleriyle tanışmalarının onların ilgi ve yeteneklerinin ortaya çıkmasında faydalı olacağını belirtmişlerdir. Sınıf öğretmenleri 12 yıllık zorunlu eğitimi öğrenciler açısından değerlendirirken uygulama öncesinde belirttikleri olumsuz görüşlerle uygulamanın birinci yılı sonunda belirttikleri olumsuz görüşler benzerlik göstermektedir. Sınıf öğretmenlerinin 60-66 aylık çocukların sınıfa uyum sağlamalarında, özbakım ihtiyaçlarını karşılamalarında ve okuma yazmayı öğrenme sürecinde sorunlar yaşadıklarını, erken yaşta başlayan çocuklarda başaramama korkusu oluştuğunu, sınıf içinde gelişimsel farklılıklarının artmasının öğrencilerin kendilerini ifade etmelerini olumsuz etkilediğini belirtmişlerdir. Araştırma sonuçlarını destekler nitelikte Aykaç ve arkadaşları (2014) 60-66 aylık öğrencilerin okula uyum sorunu yaşadıklarını, Öztürk ve Uysal (2013) 60-66 aylık öğrenci grubunun okuma yazma 
öğrenmede sorun yaşadıklarını, Doğan ve arkadaşları (2014) ile Örs ve arkadaşları (2013) araştırmalarında 60-66 aylık öğrenciler içinde başarısız olanların diğer çocukların yanında ezildiklerini, Durmuşçelebi ve Bilgili (2014) ile Örs ve arkadaşları (2013) araştırmalarında farklı yaş gruplarında yer alan öğrencilerin aynı sınıfta, okulda yer almalarının gelişimsel ve öğretimsel sorunları ortaya çıkardığını belirtmişlerdir.

Sonuç olarak, sınıf öğretmenlerinin ilkokula 60-66 aylıkken başlayan öğrencilerin akademik başarılarının diğer öğrencilere göre daha düşük olduğu, özellikle okuma ve yazmayı öğrenme süreci açısından bu yaş aralığının uygun olmadığı, bu çocukların kendilerini ifade etmekte sorunlar yaşadıklarını kısaca bu yaş aralığındaki çocukların okul olgunluğu açısından yeterli olmadıkları görüşünde oldukları belirlenmiştir. Sınıf öğretmenleri, kademelendirmeye yönelik özellikle küçük yaştaki çocuklarla büyük yaştaki çocukların aynı yerleşke içinde yer almalarının yarattığı sorunun yapılan bu değişiklikle engelleneceğini vurgulamışlardır. Ancak yapılan değişikliğin ideolojik ve siyasi amaçlı olduğu, ayrıca bu uygulama için gerekli pilot uygulamanın yapılmadığı ve alt yapının yetersiz olduğunu vurguladıkları, özellikle beşinci sınıfın ortaokul kademesine alınması ile birçok sınıf öğretmenin norm fazlası duruma düştüğünü ve haftalık ders saatlerinin beşinci sınıf öğrencileri için fazla olduğunu vurgulayarak kademelendirmeye yönelik olumsuz yönde eleştiri getirdikleri görülmektedir. 12 yıllı zorunlu eğitimin $4+4+4$ şeklinde kademelendirilmesini öğretmenlik mesleği açısından değerlendiren sinıf öğretmenleri, yapılan kademelendirmenin öğretmenlerin ders yükünü hafifleteceğini vurgulayarak kademelendirmeye olumlu yaklaşmışlardır. Ancak pilot uygulamanın yapılmaması, hizmet içi eğitim verilmemesi, programlarda gerekli değişikliklerin yapılmaması, yaş grubu farklılıklarından dolayı sınıf yönetiminin zorlaşması, okul olgunluğu yeterli düzeyde olmayan öğrenciler nedeniyle öğretim hizmeti dışında tuvalet alışkanlığı kazandırma, yemek yedirme, ilaç içirme, vb. durumlarla uğraşılması gibi olumsuz görüşler de bildirmişlerdir.

Bu sonuçlardan yola çıkılarak:

1. Okula başlama yaşının tekrar 72 aya çıkarılması ya da okula başlayacak öğrencilerin belirlenmesinde okul olgunluğu kriterinin titizlikle dikkate alınması,

2. Sınıf öğretmenlerine hitap edilen yaş grubunun farklılaşması nedeniyle gerekli hizmet içi eğitimlerin verilmesi,

3. Eğitim-öğretim faaliyetleri için gerekli alt yapı düzenlemelerinin gerçekleştirilmesi, 
4. Özellikle beşinci sınıf öğrencileri için haftalık ders saatinin daha aşağı çekilmesi,

5. Velilerin yeni kademelendirme ve uygulamada karşılaşılabilecek güçlükler konusunda bilgilendirilmesinin sağlanması,

6. Norm fazlası öğretmen sayısının en aza indirilmesi için gerekli düzenlemelerin yapılması önerilebilir.

\section{Kaynakça}

Aykaç, N., Kabaran, H., Atar, E. ve Bilgin, H. (2014). İlkokul 1. Sınıf Öğrencilerinin 4+4+4 Uygulaması Sonucunda Yaşadıkları Sorunların Öğretmen Görüşlerine Dayalı Olarak Değerlendirilmesi (Muğla ili örneği). Turkish Studies - International Periodical For The Languages, Literature and History of Turkish or Turkic Volume 9/2 Winter 2014, p. 335-348, ANKARA-TURKEY.

Doğan, S., Uğurlu, C. T. ve Demir, A. (2014). 4+4+4 Eğitim Sisteminin Okul Paydaşlarına Olumlu ve Olumsuz Etkilerinin Yönetici Görüşlerine Göre İncelenmesi. Gaziantep University Journal of Social Sciences, 13(1):115-138 ISSN: 1303-0094 (http://jss.gantep.edu.tr)

Durmuşçelebi, M. ve Bilgili, A. (2014). Yeni (12 Yıllık) Eğitim Sistemi, Karşılaşılan Sorunlar ve Dünyadaki Uygulamalardan Bazılarının İncelenmesi. Turkish Studies - International Periodical For The Languages, Literature and History of Turkish or Turkic Volume 9/2 Winter 2014, p. 603-621, ANKARA-TURKEY

Eraslan, L. (1999). Japon sosyo-ekonomik yaşamında yükseköğretimin belirleyici rolü. Gazi Eğitim Fakültesi Dergisi 19(1), 121-139.

Erden, M. (1993). Eğitimde program geliştirme. Ankara: Personel eğitim merkezi yayınları.

Ergün Öztürk, E. Ve Uysal, K. (2013). İlkokul 1.sınıf öğrencilerinin okumayazma süreçlerinin takvim yaşı yönünden karşılaştırılması. Turkish Studies - International Periodical For The Languages, Literature and History of Turkish or Turkic Volume 8/8 Summer 2013, p. 1041-1054, ANKARA-TURKEY

ERG, (2012). 4+4+4'e geçiş. Eylül 2012 bilgi ve politika notları: bilgi notu. İstanbul.

Güven, İ. (2012). Eğitimde 4+4+4 ve fatih projesi yasa tasarısı = reform mu? İlköğretim Online, 11 (3), 556-577. 
Karip, E. (1997). Eğitimde yeniliklerin uygulanmasını etkileyen etkenler. Kuram ve Uygulamada Eğitim Yönetimi, 3 (1), 63-82.

Külekçi, E. (2013). 4+4+4 eğitim sistemi kapsamında birleştirilmiş sınıf uygulamasına ilişkin öğretmen görüşlerinin değerlendirilmesi. Eğitim ve Öğretim Araştırmaları Dergisi Journal of Research in Education and Teaching Mayıs 2013 Cilt:2 Sayı:2 Makale No:40 ISSN: 2146-9199.

MEB, (2012a). 12 ylllı zorunlu eğitime yönelik uygulamalar. http://mevzuat.meb.gov.tr/html/onikiyillik/oniki.html adresinden 14/06/2014 tarihinde edinilmiştir.

MEB, (2012b). 12 yıl zorunlu eğitim sorular - cevaplar. Ankara: MEB Yayını.

Örs, Ç., Erdoğan, H. ve Kipici, K. (2013). Eğitim Yöneticileri Bakış Açısıyla 12 Yıllık Kesintili Zorunlu Eğitim Sistemi: Iğdır Örneği. Iğdır Üniversitesi Sosyal Bilimler Dergisi No. 4, Ekim 2013: 131-154

Özel İhtisas Komisyonu Raporu, (2009). Eğitim: okulöncesi, ilk ve ortaöğretim. Dokuzuncu kalkınma planı; 2007-2013. T. C. Başbakanlık, devlet planlama teşkilatı. Ankara.

Resmi Gazete. (1997). İlköğretim ve eğitim kanunda değişiklik yapılması hakkındaki kanun. http://www.resmigazete.gov.tr/arsiv/23084.pdf adresinden 14/07/2014 tarihinde edinilmiştir.

Yılmaz, T. (2006). Yenilenen 5. sinıf matematik programı hakkında öğretmen görüşleri (Sakarya ili örneği). Sakarya Üniversitesi, Sosyal Bilimler Enstitüsü, Yüksek Lisans Tezi. Sakarya.

Yılmaz, N., Taşçı, G., Fidan, M. ve Nurlu, Ö. (2014). 4+4+4 Sistem Değişikliğinin İlk Yılında İlkokul Birinci Sinıflardaki Durum: Sorunlar ve İhtiyaçlar (Erzincan Örneği). Eğitim bilimleri araştırmaları dergisi, uluslararası e-dergi. Cilt 4, özel sayı. 1 Nisan. 
B. ÖZDEN, R. KILIÇ, D. AKSU 202 